\title{
The Importance of Authentic Workplace-Based Assessment: A Study From VET Teacher Education
}

\author{
Jorunn Dahlback, Hanne Berg Olstad, Ann Lisa Sylte*, \\ Anne-Catrine Wolden \\ Oslo Metropolitan University, Faculty of Teacher Education and International Studies, \\ Postboks 4, St. Olavs plass 0130 Oslo, Norway
}

Received: 16.06.2019, Accepted: 10.07.2020, Published: 11.11.2020

\begin{abstract}
Context: This article is based on a pragmatic theoretical perspective on education, in which theoretical and practical competences are developed through experiences and participation in realworld teaching contexts. Previous research points to a lack of culture for authentic workplacebased assessment in vocational and professional education in many countries. Prior to this study, professors/authors and student-teachers in a vocational teacher education program in Norway experienced that student-teachers were unable to demonstrate comprehensive teaching competence, as examinations and assessments assess theoretical knowledge separately from practice. Research questions: 1) How can an authentic workplace-based exam during placement give student-teachers an opportunity to showcase their comprehensive teacher competence? 2) What factors are important to emphasize in such an exam? 3) How do the student-teachers demonstrate and develop comprehensive teacher competence through an authentic exam?

Methods: Using action research, professors/authors carried out sequential actions to develop a practical-theoretical exam in an authentic professional setting. This included demonstrating elements of practical and theoretical competence conducted during teaching practice. The exam involved planning in line with a guidance document and practical teaching in the classroom in VET-schools, followed by a piece of reflective writing based on teaching experiences. Supervisors and professors/authors observed the student-teachers teaching as part of multiple qualitative methods.
\end{abstract}

*Corresponding author: sylte@oslomet.no 
Findings: The empirical results show how student-teachers demonstrate and develop comprehensive teaching competence. Both the student-teacher and the supervisors in VETschools experienced the authentic exam as realistic and professionally based. The biggest challenge involved logistics: Compensating the professors'/authors' time and financial frameworks related to the observation of the student-teachers. However, this kind of authentic assessment leads to stronger coherence between both theory and practice, and between the vocational teacher education at the university and the VET in upper secondary school. It also supports the job-relevant learning process towards comprehensive teacher competence.

Conclusions: This kind of authentic assessment i.e. an authentic exam requires an understanding of the complex role of teachers within their professional context in VET. Therefore, the professors/authors see the need of a broader, more comprehensive teacher competence in VET to meet the work life needs for competence.

Keywords: Comprehensive Teacher Competence, Relevance, Coherence, Work-Based Education, Work-Based Assessment, Competence-Based Exam, Vocational Education and Training, VET

\section{Introduction}

International research highlights the lack of cooperation between education institutions and working life, showing challenges in both vocational and professional education across a number of North European countries, including Denmark, UK, Germany and Norway (Billet, 2014; Gessler, 2017; Gulikers et al., 2017; Hiim, 2017; Wahlgren \& Aarkrog, 2012; Young, 2004). One of these challenges is meeting the need for relevant content, teaching and assessment in conjunction with the need for demonstrating competence in working life. Research conducted by Baartman et al. (2013) and Grollmann (2008) shows that in order to ensure quality, assessment must be undertaken within the context in which the profession is executed - authentic assessment for work. Grollmann's (2008) research explicitly addresses the need for an assessment where there is a close relationship between practice and theory. This kind of assessment form also requires an understanding of the complex role of teachers within their professional context as teachers in vocational education and training (VET), i.e. hairdressing, cabinetmaker and florist educations. The Norwegian term of "vocational education alludes to VET playing out in an education context (even school), while vocational training hints at how a vocation (or occupation) is constituted at the workplace" (European Centre for the Development of Vocational Training [Cedefop], 2017, p. 51). This kind of complex understanding is required to avoid the problem of lack of relevance, which has traditionally characterized professional education. More specifically, this lack of relevance has been typical of educational programs where theory and practice are taught separately (Billet, 
2010; Hiim, 2017; Nasjonalt Organ for Kvalitet i Utdanningen, 2006). International research suggests that in order to ensure quality in higher professional education and training (PET), i.e. vocational teacher education at university level, the educational program needs to be jobrelevant and have strong bonds to working life (Billett \& Choy, 2013; Grollmann, 2008; Heggen et al., 2015; Mulder, 2017). Professional work-centred education is a way to help address this problem of lack of relevance in both VET and PET. Professional work-centred education is when the content, teaching methods and assessment in education are all based on and related to the tasks and functions of professional practice (Hiim, 2013, 2017; Sylte, 2018), but this context is often lacking in both VET and PET, i.e. a teacher education (Billett, 2010; Sullivan, 2005). Political guidelines for teacher education at the PET-level in Norway stress that workplace-based practice should be emphasized in teacher education, as practical relevance is a recurring challenge in most teacher education programmes at university level, including the vocational teacher education (Ministry of Education, 2017). Regarding this challenge, Baartman et al. (2013) also point out that "social skills and attitude in teacher education are particularly difficult to acquire through theory" (p. 11). Sylte's (2018) research also indicates a lack of focus on profession-related assessment and how it can be achieved, in both teaching education and other PETs, i.e. nursing, police and engineering educations.

This paper is based on data from an action research project. The aim of this project was to examine whether a workplace-based comprehensive exam in vocational teacher education on university-/PET-level, i.e. an authentic exam, during vocational-student-teachers (student-teachers) practice placement in VET, would offer student-teachers at the vocational teacher education student-teachers had the opportunity to demonstrate comprehensive teacher competence. The term "comprehensive teacher competence" in this paper focuses on a holistic teacher competence that includes professional subjects and key competences, such as collaborative ability, independence, creativity as well as innovative and critical thinking (Sylte, 2018). The competence that the student-teachers must demonstrate is the ability to plan, teach and assess in VET, as well as their ability to solve complex challenges related to individual pupils and the job-relevant teaching session in VET. This paper aims to show that comprehensive teacher competence can be described as: "A competence consists of an integrated set of knowledge, skills and attitudes, where also personal characteristics and aspects of the professional functioning influence the development of competences in some way" (Koenen et al., 2015, p. 2). Comprehensive teacher competence also includes the student-teachers understanding of the need for relevant workplace-based learning in VET, and understanding of the vocational profession, its function in society, its culture, tradition and development (Sylte, 2018).

The authentic exam is a workplace-based exam in the vocational teacher education on the PET-level, which was implemented in an authentic VET-school-context (upper secondary school, pupils age 16-19 years). It will be defined in the next section. 
The authors will first present the Norwegian context, and next provide an overview of the fundamental components of authentic exam as outlined in previous research. Then the theoretical basis will be explained, before describing the research approach and present the results. Finally, a comparison of the findings to previous research in the discussion before concluding, pointing to some implications of the analysis.

\section{Norwegian Context}

Vocational teacher education at Oslo Metropolitan University (OsloMet) in Norway is a three-year bachelor level degree programme with a strong emphasis on the teacher's job tasks in VET. Over a three-year period, the student-teachers undertake 70 days of pedagogical teaching practice, spread over four placements (Ministry of Education, 2013). Supervisors (teachers in VET with a mentoring responsibility) in upper secondary school assess the placements by using a pass/fail grading scale.

The student-teachers receive written feedback in five competences: Social competence, subject competence, vocational-didactic competence, professional ethics competence, and adaptive and development competence (Ministry of Education, 2013). Vocational-didactic refer to how teachers undertake practical-theoretical planning, implementation (content and teaching methods) and assessment, and critically analyses the teaching in VET, in both upper secondary school and university level (Hiim \& Hippe, 2001). Aside from the assessment of teaching practice by a supervisor, there has been no tradition for an authentic workplace exam in vocational teacher education (Haaland \& Vagle, 2016; Sylte, 2018).

The four authors as assistant professors/ associate professors/professor (professors/authors) who teach student-teachers at the university, experienced that their student-teachers were unable to demonstrate comprehensive teacher competence, as theoretical knowledge was assessed separately from practice. This lack of a suitable assessment form for comprehensive teacher competence formed the grounds for an action research project in vocational teacher education, initiated by the four professors/authors to research their own practice. An authentic exam for student-teachers in practice placement in VET-schools was tested through an iterative process in three sequential actions. student-teachers. This led to the research questions regarding how an authentic workplace-based exam in teaching practice might give student-teachers an opportunity to showcase their comprehensive teacher competence. The components that comprised the exam were that the student-teachers:

1. Plan their teaching in line with a guidance document, with vocational-didactical and pedagogical reasons for why and how to conduct the teaching session.

2. Teach pupils in authentic situations in VET. 
3. Produce a piece of reflective writing about their practical teaching considering pedagogical and vocational-didactical theory immediately after the teaching (when they still remembered what happened in class).

This authentic exam is a summative assessment as a part of an authentic assessment implemented in a realistic and complex VET-school-context. Authentic assessment can be defined as an assessment form were student-teachers can demonstrate their comprehensive professional teacher competence instead of proving their accumulated fragmented theoretical knowledge. This is an assessment that involves supporting the job-relevant learning process towards comprehensive professional competence which is based on the competence needed in professional practice (Sylte, 2014, 2018). The authentic exam was inspired by research e.g. Billett and Choy (2013), Grollmann (2008) and Mulder (2017) who emphasizes the need of job-relevance and strong bonds to working life. The working life for the student-teachers in this context was their practice placement in different VET-schools. Gulikers et al's (2017) research on the importance of authentic tasks in assessment and Miller's (1990) four-level assessment pyramid, also influenced the authentic exam. This authentic exam involves all levels, and especially the three upper levels of Miller's (1990) assessment pyramid. Miller (1990) divides competence assessment into four levels in a pyramid: The lowest level is knowledge (knowing), the second level is competence (knowing how), the third is performance (showing how), and finally the highest is action (doing), in a realistic and complex context. The assessment form, i.e. this authentic exam is based on authentic workplace-tasks (Gulikers et al., 2017). Simultaneously, it is important that the professional competence requirements are reflected in the assessment criteria (Baartman et al., 2013). Authentic assessment is elaborated in more detail in the next section.

\section{Previous Research Related to Authentic Assessment}

Research shows that coherence is necessary if education is to be perceived as relevant for work-life competence requirements. Achieving this kind of relevance, requires strong cooperation between education institutions and work life on relevant content, teaching and assessment (Billet, 2014; Canrinus et al., 2015; Grollmann, 2008; Hiim, 2017; Smeby \& Heggen, 2012). A comparative research study on teacher education encompassing five countries shows that student-teachers from study programmes with no specific focus on a correlation between theory (at their universities) and pedagogical practice (in their school placements) experienced less coherent learning objectives (Canrinus et al., 2015). This finding points to the need for workplace-learning and authentic assessment of studies involved in practice placements (Billett, 2014; Mulder, 2017). Grollmann's (2008) research on quality in vocational teacher education addresses the characteristics of high-quality vocational teacher educa- 
tion in the US, Denmark and Germany. In order to assess the complexity of the teacher role in VET, Grollmann (2008) states that the assessment must be undertaken in the context in which the profession is practiced. The results of his research show that vocational teacher education involves complex competence areas that are difficult to separate into discrete units.

Torrance's (2007) research shows that education on learning-supportive assessment has received a greater focus in recent years. Assessment practice has shifted the focus from an assessment of learning to an assessment for learning, which involves both formative assessment and self-assessment with a focus on learning. A learning-supportive assessment with formative strategies and democratic processes (which were important goals in the authors' actions) promotes learning. When students are actively involved in the assessment process, both motivation and learning outcomes are strengthened (Hattie \& Timperley, 2007).

Dutch research points out, however, that neither self-assessment nor formative assessment is enough: A key challenge is whether professional competence requirements are reflected in the assessment criteria (Baartman et al., 2013). The presence of professional competence requirements in the assessment criteria would necessarily involve a professionally related assessment where the student-teacher is given the opportunity to show comprehensive teacher competence (Grollmann, 2008; Sylte, 2018).

Regarding Miller's (1990) four levels (knowing, knowing how, showing how and doing in a realistic and complex context), Gulikers et al. (2017) argue that "this highest level requires an integration of knowledge, skills and attitude in competent performance, assuming that competent performance cannot be done when underlying knowledge and skills are not internalised" (p. 4). The professors/authors' previous experience with assessment in vocational teacher education implied mostly Miller's two lowest levels (knowing and knowing how) where the focus was on a student's accumulation of knowledge through written assignments. Authentic assessment of comprehensive teacher competence however requires methods that touch upon all levels of the pyramid and especially prioritise the highest level (doing). The challenge is that authentic assessments that include Miller's "higher levels of the pyramid (showing how and doing) are not often included in summative assessments" (Baartman et al., 2013, p. 980).

Baartman et al.s (2013) findings resonates with the authors' experiences from vocational teacher education, where the student-teacher's placement is assessed separately from all the other exams in the study programme. Baartman et al.s (2013) research shows: " [Supervisors] do not act as assessors (reproducibility of decisions), do not know and therefore cannot accept the assessment criteria (transparency and acceptability), and the assessments are not always practically relevant or take place in the work context (authenticity)" (p. 988). However, it is a problem that supervisors do not know enough about the content of the vocational teacher education curriculum so that they can assess students' competence appropriately. Thus, we see the need for involving the placement-schools and the supervisors in an authen- 
tic exam. Gulikers et al. (2017) show that students experienced authentic exams as much more meaningful and realistic than previous assessments methods. Student motivation increased, and the formative learning prepared the students much better for their further work in VET, which the authors see as a transferable skill for the student-teachers who will become teachers in VET.

An assessment that involves supporting the learning process towards comprehensive professional competence is based on the competence needed in professional practice, which simultaneously includes numerous competence goals in several subjects (Sylte, 2014). In the assessment of work tasks and functions, several different learning outcomes are included when a student-teacher plans, conducts and assesses a teaching session. Aspøy et al's (2017) study shows that while teachers in VET must have good subject competence in the subject they are teaching, such subject specific competence is not enough: "In addition to subject and pedagogical competence, the informants emphasize the teacher's relationship between competence and interaction skills" (p. 59). Further, the importance of contact and confidence with pupils is also emphasized. This emphasis also points to the need for coherence with authentic assessment, which involves comprehensive teacher competence. The same discussion on the need for authentic assessment is ongoing in a European context, where Mulder (2017) argues that education institutions have to step out of their comfort zone, and: "move away from memorising textbooks and doing reproductive tests" (p.3). In sum, it is well documented in the literature that teacher education requires a type of assessment which is different from that which separates knowledge, skills, attitude, responsibility and autonomy. As a consequence, students need to be given the opportunity to demonstrate comprehensive professional competence rather than proving their accumulated fragmented theoretical knowledge (Billett, 2010; Canrinus et al., 2015).

Previous research also indicates that assessment in professional education is characterized by a culture of measuring theoretical knowledge instead of comprehensive competence (Haaland \& Vagle, 2016; Sylte, 2018). Another OsloMet study which examined the implementation of practical exam (in another vocational teacher education subject) showed that the student-teachers gained greater insight in vocational teacher competence than with the previous version of the exam (Haaland \& Vagle, 2016). Even though approximately twothirds of the programme's learning outcomes were comprised of learning practice-based teacher skills, and then practicing and understanding the teacher's work in VET, previous exams had not taken this into account (Haaland \& Vagle, 2016).

Goh and Zukas (2016) also emphasize the importance of the supervisor's role during the student-teachers' school placements in a European context, noting that: "(...) subject knowledge which is valued in one context does not necessarily help the learning of individuals in becoming a vocational teacher in another context" (p. 263). Moreover, they also point out the need for a stronger focus on broader teacher competences, in which the different 
functions of a school are included in teacher education at the university. Our research is also about coherence through authentic assessment, but we focus on empirical examples on how student-teachers can show comprehensive teacher competence in an authentic workplacebased exam.

\section{Assessment in a Pragmatic Knowledge Perspective}

A pragmatic knowledge perspective (Dewey, 1910; Schön, 1983) characterized this project. A pragmatic perspective on education "implies that experience and language are considered a process where concepts are developed through participation in practical contexts" (Hiim, 2013, p. 313). The core of this perspective consists of contextual learning which is based on job tasks and functions, requires learning and assessment through action, experience and reflection (Dewey, 1910; Schön, 1983). A significant difference between pragmatic professional pedagogic relational thinking in relation to conventional pedagogy is that curricula content, teaching and assessment are based on actual work tasks and practice, instead of context-free abstract theory (Hiim, 2013).

The development of comprehensive teacher competence requires tasks to be realistic and practice-based, as it is through reflecting on the pedagogical and vocational-didactical theory related to the practical implementation that coherence is achieved. Comprehensive teacher competence implies a beginner level of expert knowledge, in which the student-teachers can distinguish between different situations requiring different actions (Dreyfus \& Dreyfus, 1986). The student-teachers should develop competence not only about what to teach, but also how and why they teach. They should develop an understanding and an emerging expertise as teachers in VET. This approach also emphasizes the importance of learning to learn in a lifelong learning perspective (Billet, 2010; Dreyfus \& Dreyfus, 1986). In this context, competence entails being able to solve problems and carry out work tasks in both known and unknown contexts, as well as the ability to reflect and think critically (Mulder, 2017; Ministry of Education and Research, 2015-2016). Previous studies have revealed a need for authentic forms of competence assessment, however there is still a lack of research showing how such an assessment might be accomplished, something this article will address.

To be able to examine how such an assessment might be accomplished, this project analyse how authentic workplace-based exams that showcase the student-teachers' comprehensive teacher competence can be developed. To conduct such an analysis, the authors chose action research which is presented in the next section. 


\section{$5 \quad$ Method}

\subsection{The Research Design of the Project}

The action research approach was primarily inspired by pedagogical action research (Hiim, 2010; Stenhouse, 1975; Winter, 1989). The authors researched their own practice as professors/authors in interactions with supervisors and student-teachers. According to CochranSmith and Lytle (1993), professors/authors researching their own practice has advantages: "This research recognizes that teacher are uniquely positioned to provide an insider's view that makes visible the way that student-teachers and teachers together construct knowledge" (p. 43). It was important for the authors to gain deeper insight into the student-teachers' practices. The authors were thus seeking a deeper understanding and insight into how the student-teachers and the supervisors jointly construct pedagogical and vocational-didactical knowledge as teachers in a VET-school-context. Therefore, the action research design was chosen as actions were performed with an authentic exam in collaboration with the studentteachers and their supervisors in VET-schools. The three research questions (RQ) were:

1. How can an authentic workplace-based exam during placement give student-teachers an opportunity to showcase their comprehensive teacher competence?

2. What factors are important to emphasize in such an exam?

3. How do the student-teachers demonstrate and develop comprehensive teacher competence through an authentic exam?

\subsection{Empirical Data Basis}

The participants in the project were 52 second-year undergraduate students-teacher at the vocational teacher education in the university and their supervisors in their placement in VET at upper secondary school. Most of the student-teachers were women who were between twenty-five and fifty years old. A small number of student-teachers had previous teaching experience. The project was carried out over a three-year period from 2016 to 2018. The action research were carried out in three sequential iterations as authentic exams in the student-teachers' practice placement in school. The actions and empirical data based on the various qualitative research methods are illustrated in Figure 1. 


\begin{tabular}{|l|l|}
\hline Empirical Data Foundation & $\begin{array}{l}\text { Participants: Supervisors and } \\
\text { Student-Teachers }\end{array}$ \\
\hline $\begin{array}{l}\text { Three actions comprising } 52 \text { authentic exams in student-teachers } \\
\text { placement in VET at upper secondary schools (2016-2018) } \\
\text { 2016: } 17 \text { students and 13 supervisors from 10 different schools } \\
\text { 2017: } 16 \text { students and 14 supervisors from 11 different schools } \\
\text { 2018: } 19 \text { students and 15 supervisors from 13 different schools }\end{array}$ & $\begin{array}{l}52 \text { student-teachers, } \\
\text { supervisors and four } \\
\text { professors/authors }\end{array}$ \\
\hline Interviews & $\begin{array}{l}52 \text { students and 42 } \\
\text { supervisors }\end{array}$ \\
\hline Two dialogue meetings with students as a basis for evaluation & 52 students \\
\hline Guidance document (students' teaching plan and theoretical perspectives) & 52 students \\
\hline Observation logs from 52 teaching sessions & $\begin{array}{l}42 \text { supervisors and four } \\
\text { professors/authors }\end{array}$ \\
\hline Reflective writing assignments & $\begin{array}{l}52 \text { students } \\
\text { 42 supervisors and four } \\
\text { professors/authors }\end{array}$ \\
\hline Interviews/dialogue with assessors & \\
\hline
\end{tabular}

Figure 1: Empirical Data

Various qualitative enquiries were used, all focusing on the opportunities and challenges the practical exam might entail for the student-teachers related to comprehensive teacher competence. Each of the student-teachers' teaching sessions in part two of the exam were observed and assessed by a supervisor and a professor/author using systematic categories, documented in semi-structured logs. The assessment criteria included: 1) Relationship and dialogue with the pupils (pedagogic), 2) The role of the teacher and classroom management (pedagogic), and 3) The correlation between the teaching plans, and what occurred during the teaching session (pedagogic and vocational-didactic). Criteria such as responsibility, autonomy, attitude and social skills (such as classroom management and communication with pupils) are impossible to assess only through a written exam alone. Therefore, these three assessment criteria were important to assess in part two in the authentic exam. This is in accordance with: Miller's (1990) showing how and doing in a realistic and complex context, Gulikers et al's (2017) integration of knowledge, skills and attitude in competent performance, and Sylte's (2018) ensuring that the student-teachers develop comprehensive teacher competence.

The role of the professors/authors also involved a dialogue with the supervisors on the observations and analysis of the reflective writing. The supervisors gave formative oral feedback to the student-teachers based on their observations, while the professors/authors gave written feedback to the student-teachers based on their planning, observations and reflection notes. The actions were evaluated through "dialogue meetings" in which all the student-teachers summarized their experiences with the practical exams in groups (Reason \& Bradbury, 2008). All thoughts and summaries were documented on posters and further summarized by the authors. In addition, the authors conducted semi-structured interviews with the supervisors and a random sample of the student-teachers about their experiences with the exam (Patton, 2015). 


\subsection{Analysis, Validity and Relevance}

The data were analysed and synthesized during the project period to further develop the actions and to notice any emerging contexts and patterns (Patton, 2015). The analysis was conducted using the analysis tool HyperRESEARCH.

The authors defined categories to produce original and valid knowledge that others could learn from (Hiim, 2010; McNiff \& Whitehead, 2006). The categorization was primarily based on theoretical concepts from our pragmatic didactical knowledge perspectives. The main categories for analysis were the areas of competence specified in the national curriculum: Subject competence, vocational-didactic competence, social competence, adaptive and developmental competence, and professional ethics competence. The sub-categories were Miller's (1990) four levels of competence assessment: Knowledge, knowing how, showing how and doing in a realistic and complex context.

A common critique of action research is that it gives too much leeway to researcher's judgment and ability to evaluate, such as by Grimen (2004). The authors have attempted to accommodate this criticism by discussing and reflecting critically in a dialogue with the supervisors and the student-teacher about their experiences with the actions (Reason \& Bradbury, 2008). Likewise, the authors were conscious of their research role as professors/authors and sought to retain a certain amount of professional distance, to limit any subjectivity influencing the analysis.

\section{Results From the Action Research Project}

The three iterations of the actions will be presented together based on the observations and evaluations before discussing the challenges and opportunities the exam offered. The results are structured according the three research questions (RQ1, 2, 3).

RQ1: How can an authentic workplace-based exam during placement give student-teachers an opportunity to showcase their comprehensive teacher competence?

In the first part of the authentic exam, the student-teachers detailed their plans in a guidance document structured around the vocational-didactic categories of learning goals, content, pupils' learning conditions, frameworks, the learning process and assessment. In the first iteration, the theoretical basis was almost non-existent in the student-teachers ' reflection notes. Consequently, the professors/authors discussed how to integrate Miller's (1990) first and second levels for assessment in the competence pyramid (knowing and knowing how). Advice was given to the student-teachers to develop their teaching plans and include pedagogical and vocational-didactic theory. In the following two iterations, the reflections were 
substantially more theoretically based and during the authentic exam, many student-teachers wrote that they experienced mastery of comprehensive teacher competence.

The student-teachers noted their own changing and developing competence through the planning and implementation of the teaching session. For example, one student-teacher reflected on overusing the guidance document with a theoretical basis when planning the teaching session. "I have seen that my teaching was more dialogue-oriented teaching than what I thought, which is based on a more critical view of knowledge and humanistic values." Another student-teacher reflected on their relational and social skills related to pedagogical theory: "I see the importance of Bandura's three perspectives because a lack of confidence in interaction with others will probably provide a poor learning process for the pupils." Many student-teachers reflected on the significance of varied teaching methods, in addition to the need for relevant vocational content based on job functions in vocational teaching. Here, the student-teachers were assessing their own learning through action, experience and reflection. Another student-teacher reflected on their own pedagogical competence in the class: "Bruner's theory of scaffolding is important in this class. When they reflected and shared some of these thoughts with the rest of the class, I feel that it has as much, if not more weight than if I say the same thing." In the reflection notes, most student-teachers showed that they reflected both in and on action.

RQ2: What factors are important to emphasize in such an exam?

In the first and second iterations, the student-teachers performed reasoned connecting their teaching session planning in accordance with the guidance document, justifying the teaching session plan with vocational didactical and pedagogical reasoning. Here they showed how they planned to manage pupils' learning conditions, the frameworks for teaching, the content and structure, the learning goals, the learning process and how the teaching session should be assessed in a whole. By making these connections, many student-teachers showed that they had begun to develop an understanding of comprehensive professional pedagogy and vocational-didactical relationships through the three parts of the exam. However, in the reflective written assignment after their teaching session, there were differences in how they explained their choices considering relevant theory. Some student-teachers separated the theory from what they were planning to do, while other student-teachers integrated it well. In the second and third iterations, most of the student-teachers integrated the theory well. This indicates that how the exam was introduced and how the student-teachers were made aware of the assessment criteria were of significance. 
RQ3: How do the student-teachers demonstrate and develop comprehensive teacher competence through an authentic exam?

According to the observations that the professors/authors made in the teaching sessions, the student-teachers exhibited teaching competence through an understanding of pedagogical and vocational-didactic theory in practice. "I was tested on what it means to be a teacher," said one of the student-teachers. During their teaching, the student-teachers had to keep to the framework and the pupils' learning conditions in the class. "I experienced that I could deal with unforeseen situations and challenges in the classroom", said another studentteacher. The student-teachers also showed vocational-didactic competence by using teaching methods that emphasized contextual learning based on job function. As one of the supervisors said, "the teaching was vocational and differentiated through varied teaching methods and based on the pupils previously documented learning conditions". The student-teachers also showed teacher competence through the confidence they demonstrated, the subject content and the teaching methods they chose, as well as through their pupils' participation and engagement. A supervisor's statement (about a student-teacher) from the interviews can serve as an example of how the student-teachers demonstrated this kind of competence: "Good subject content in a relevant topic, which the student-teachers presented in a varied and good way, shows good digital skills and dares to challenge themself." The assessment, conducted in the school context (the student-teachers ' placement) where the teaching profession is practiced, provided room for the student-teachers to show the complexity of the teacher role in VET.

Many of the student-teachers also showed responsibility, autonomy, good class leadership and social skills. These were demonstrated in the way they handled unforeseen situations, which occurred during the teaching sessions observed by the professors/authors and supervisors. Some student-teachers showed good communication and relationship building skills in addition to subject competence, through the contact and trust they developed with each pupil. One supervisor's observation log read: “Good class management, nice lesson structure, varied, ethically conscious, good values, sees all the pupils and takes them seriously, good at concretizing and leading the process. Would believe the student-teacher- has worked as a teacher for many years." Most of the student-teachers showed that they had established good relationships with the pupils while guiding and engaging them in a dialogue during the teaching situation. One supervisor wrote in the observation log that the student-teacher had "the ability to handle demanding pupils in a calm and good manner (...) which extends even to the most demanding pupils. Proximity to pupils motivates while at the same time giving them room to work." This indicates confidence in the role of the teacher in VET. Another supervisor indicated that even a student-teacher who had had low self-confidence managed to show her potential as a teacher during the teaching session: "Her relations and social skills are very strong; she sees all the pupils." 


\section{Opportunities and Challenges With an Authentic Exam}

The results of how an authentic exam in teaching practice can give student-teachers the opportunity to demonstrate their comprehensive teacher competence will be discussed here. The results from the professors/authors' observations, evaluations and interviews indicate that both the student-teachers and the supervisors experienced the authentic exam as strongly realistic for working life. This is in line with Baartman et al. (2013) and Hiim (2017). The exam provided greater opportunities for student-teachers to show comprehensive teaching competence and included all of Miller's (1990) four competence levels, which is important for professionally relevant assessment. The results indicate that this form of assessment contributes to a learning process in which student-teachers develop authentic pedagogical and vocational-didactic competence. Being able to demonstrate responsibility, autonomy, relationship and social skills, and class management in close association with subject competence are all examples of this. Aspøy et al. (2017), Goh and Zukas (2016) and Grollmann (2008) all point to the necessity of focusing on a broader competence base in teacher education, which can be seen in the context of comprehensive teacher competence (Sylte, 2017). The studentteachers confirmed that they were able to showcase their confidence in the classroom, an ability to lead and motivate individual pupils, as well as the whole class. One student-teacher said that they had been "tested on what it means to be a teacher in VET." The supervisors also expressed similar statements, such as the following: "[it was] great with this authentic exam, because it is important that the student-teacher functions in the classroom - it is not enough to write about pedagogy and Vygotsky, although theory is important to understand what happens in the classroom."

The authors can also see the need for student-teachers to have exams where they explain and discuss theoretical standpoints: for example, Vygosky's theory about learning at Miller's first, second and third level. On the other hand, there's also need for the presence of professional competence and skills in the assessment criteria (Baartman et al., 2013). The authors therefore argue that an authentic exam offers a more relevant and professional assessment form than the traditional / written assessment forms. This is because the planning, teaching and assessment that the student-teachers must undertake covers all the levels in Miller's (1990) pyramid, Gulikers et al.'s (2017) integration of knowledge, skills and attitudes in competent performance and Sylte's (2018) development of comprehensive teacher competence. Vocational-didactical planning, implementation and assessment are all integrated. As Dewey (1910) and Schön (1983) also emphasize, this emphasis on integration highlights the importance of seeing action, experience and reflection in the same context in order to achieve lasting learning. This authentic exam gave the opportunity to build student-teachers' comprehensive teacher competence through their own planning, teaching, and self-assessment, which included reflecting in and on action (Baartman et al., 2013; Schön, 1983). 


\section{Workplace-Based Authentic Exam in a Practice Context}

Through the exam the collaboration and dialogue between the university and the supervisors in schools were strengthened, via joint evaluation of the student-teachers. In Norway, there are political guidelines stating that the schools involved in the practice placements will become more responsible for teacher education in the future, and this shift will also require closer cooperation and greater coherence between schools and universities (Ministry of Education, 2017; Smeby \& Heggen, 2012). After an observation, one supervisor stated: "I get insight into what to consider - what to look for, which also applies for the entire teaching practice." This form of exam offered closer ties between teacher education and the field of practice, and between theory and practice - in simpler terms - coherence (Canrinus et al., 2015). Several supervisors thought the authentic exam in school strengthened the quality of vocational teacher education, as the student-teachers were better prepared than in other teaching sessions during practice placements in school. Another supervisor stated: "What makes the situation different is that the student-teacher wants to show everything they know about teaching methods, etc., more so than in a normal situation."

Still, many student-teachers were nervous before the authentic exam, which was a challenging endeavour. This may be because they knew they were being observed by both the supervisor and the professors/authors while they were teaching. Other factors might have been their awareness of the unpredictability of the pupils' attendance and behaviour. One supervisor said that they had found it to be: "a demanding exam for the candidate, with a lot of internal stress, but good in relation to being teachers, [it] shows natural teaching and not an 'artificial' session/situation." Most student-teachers said that the form of the exam triggered stress, but at the same time gave a strong sense of achievement afterwards. The student-teachers showed competence in responsibility and autonomy by coping with stress and dealing with unexpected situations. The following is a typical quote from the interviews with student-teachers: "I was very nervous, but in retrospect I found the practical exam as a very useful and a positive experience." Another said that she had: "experienced the exam as incredibly demanding, far beyond my comfort zone, but having tackled so much stress, I felt a sense of achievement and I felt more confident afterwards." The combination of the stress the student-teachers felt, relieved by the experience of coping, is interesting in relation to Antonovsky's (2000) theory that stress management is not about what we are exposed to, but rather with our ability to cope with what is happening. Coping with the stressful situation was perhaps what made so many of the student-teachers feel good about it afterwards.

The biggest challenges in the implementation of this type of authentic assessment involved logistics: compensating professors/authors and supervisors for their time, and the financial frameworks related to the observation of the student-teachers. The geographical distance between many of the schools and the university is considerable, and the authors discussed videotaping the teaching sessions instead of being physically present. However, there are strict 
regulations on privacy in schools, and it would not be enough to simply film the studentteacher, as their reactions and interaction with the pupils were also important to observe. It was therefore considered vital to be physically present in the schools, but arguably if authentic assessment is to be scalable and sustainable, this is also an area that needs to be further developed and considered in future collaborations with the practical placement schools.

\section{Authentic Exam: Planning, Teaching and Reflection in and on Teaching}

Some supervisors experienced challenges with the situation because it was "artificial" for the pupils. For example, one of the supervisors said that "the exam situation clearly affected the class." At the same time, most supervisors experienced that the pupils behaved as they usually did, with one saying, "I thought the pupils would behave better in this session, but they behaved as usual." The time frame for the student-teachers' teaching was a challenge for some, with several supervisors making statements such as: "A little bit unrealistic with a session where a student-teacher is assessed in the middle of a period. The student-teacher performed much weaker in the exam than in previous teaching sessions." "The student-teacher had planned the session as part of a longer segment consisting of many class sessions. [There] should have been a teaching situation where the examiner, for example, observed the start-up, a middle session and the finish."

Because both the student-teachers and the supervisors experienced a 45-minute teaching session as too short for the student-teachers to show comprehensive teaching competence, this was changed to 90 minutes in the second and third iterations, which proved more successful. Nonetheless, this is still a short time to carry out vocational teaching assessment.

Some student-teachers stated that it would have been better with an oral reflection instead of a written reflection. However, one student-teacher wrote in their reflection piece: "I'm glad it was a written and not an oral reflection, as I like to think a little before I answer". Another reflection from the same student-teacher was that "the time given was ok, but I couldn't think about the theory, I was too worn out. It became more of a self-assessment and reflection on what had happened there and then".

Several student-teachers said it was difficult if not impossible to write afterwards about what they had done, and they thought it was of great importance that they were observed in action. A typical quote was: "I see that I couldn't have managed to write about what you observed." Many student-teachers experienced the opportunity to show their "tacit knowledge" as positive and were happy to have been given the chance to show that they could combine theory and practice into action. According to Polany (1996) not all knowledge can be verbalized, which is an argument for showing this unarticulated expertise in practice in this action research project. 
The student-teachers indicated that receiving quick feedback in both the oral and written assessment was supportive of learning. One student-teacher said that it was "good to get such a thorough response afterwards (...), [it] gave a good feeling, but I have to read more theory to be able to use it to reflect." This comment supports theories that assessment for learning is of importance for student-teacher learning, even when it involves an assessment of learning in an exam situation (Torrance, 2007). Feedback strengthens motivation and learning outcomes (Hattie \& Timperley, 2007). European research also points to the challenges of professional competence requirements not being adequately reflected in the assessment criteria (Baartman et al., 2013; Grollmann, 2008; Gulikers et al., 2017; Mulder, 2017). This situation is reflected in Baartman et al.'s (2013) research about working life, which often does not know about, and/or does not understand the assessment criteria for student-teachers, which in turn makes it difficult to involve such workplaces in student-teacher exams. However, this is made easier in teacher education where the placements supervisor has pedagogical competence.

In addition, this authentic exam for work was conducted as a collaboration between the supervisors and the professors/authors. The authors have developed empirical examples on how to assess comprehensive teacher competence, based on integrating the needs of both work life and school competence into the assessment criteria. It is not enough to assess pedagogical theory separately from practical teaching. However, it was found that the authentic exam did not accommodate for the student-teachers to elaborate on theoretical knowledge detached from practical context (for example on Miller's (1990) first and second levels) to the same extent as conventional theoretical examinations student-teachers. Instead, the authentic exam provides an opportunity for student-teachers to develop teacher competence in teaching planning with relevant theoretical content in a practical context. They also develop an expertise in being able to articulate how and why they teach, in compliance with utilising all four levels of Miller's (1990) assessment pyramid.

\section{Comprehensive and Authentic Assessing Gives Opportunity to Showcase Comprehensive Teacher Competence}

Comprehensiveness was achieved through a combination of preparation by utilising a guidance document, practical teaching and a reflective writing exercise. Here, the studentteachers showed that they were able to distinguish between different situations that require different actions in practice. For example, one student-teacher said that they "felt that I was able to show that I tackled unforeseen situations and challenges." The student-teachers showed competence in solving problems and performing work tasks in both known and unknown contexts, in addition to comprehension and an ability for reflection and critical thinking, as well as the ability to learn - as displayed in their reflective writing (Billet, 2010; Ministry of Education and Research, 2015-2016, p. 28). The student-teachers would not have been able 
to achieve this in just a practical or theoretical exam. Hence, it is clear that this type of exam contributes to the student-teachers developing insight and discernment at the starting level of expert competence as teachers in VET (Dewey, 1910; Dreyfus \& Dreyfus, 1986), which also includes all Miller`s (1990) levels.

An important dimension in this authentic exam is the possibility to show a comprehensive teacher competence which includes Miller's (1990) all four levels, and especially the second, third and fourth level, knowing how, showing how and doing in a realistic and complex context. This contrasts with conventional theoretical exams where student-teachers only show Miller 's (1990) first and second level, knowing and knowing how. In the conventional sense, theory is often valued more highly than practice. "In theory, practitioner research may be an attractive alternative to traditional research, but teachers and teacher educators carrying out practice-based research often meet practical problems" (Lunenberg et al., 2007, p. 21). Based on this project's results, it is argued that an authentic exam shows that comprehensive teacher competence is of a more complex nature and a higher expert level is achieved than if a student-teacher only explains and discusses theory in isolation from the practical context. If the aim is to show academic writing skills and knowledge acquisition other exam forms might be suitable, but to be able to show comprehensive teacher competence, it is necessary to see the student-teacher in action in their appropriate context.

\section{Conclusions: The Importance of Authentic Exams in Teacher Education}

This research project has provided concrete empirical examples of how a workplace-based exam in an authentic professional setting might be accomplished. The success factors of the authentic exam are based on three components: 1) The first was planning in line with a guidance document where student-teachers had to justify how and why they chose their selected content and teaching methods in relation to job-relevant pedagogical and vocationaldidactical theory. 2) The second was practical teaching in a realistic and complex context, where the student-teachers showed that they handled and solved complex teaching situations that could occur in the classroom. 3) The final component was a piece of reflective writing. Student-teachers reflected on what, how and why their teaching went as it did. Through this assessment / authentic exam, they showed an understanding and development of expertise in comprehensive teacher competence.

On one hand, an authentic exam during the student-teachers' practice placement in VET-schools gives them the opportunity to show their comprehensive teacher competence, including social skills, responsibility and classroom management. On the other hand, the results also show that other exams might be suitable if the goal is to demonstrate academic writing skills and knowledge acquisition. Simultaneously, previous research, i.e. Baartman et 
al. 2013), Billett and Choy (2013), Grollmann (2008), Gulikers et al. (2017) and Sylte (2018), has pointed out that teacher education requires a type of assessment which is different from that which separates theory and practice.

Vocational teacher education involves complex competence areas that are difficult to separate into discrete units (Grollmann, 2008). In order to ensure quality in vocational teacher education, these results show that assessment must be undertaken within the context in which the profession is executed - authentic assessment for work. The results also show that this kind of assessment requires an understanding of the complex role of teachers within their professional context as teachers in VET. Therefore, the need of a broader, more comprehensive teacher competence in VET to meet the work life needs for competence, is shown to be important by the results in this study. The results also show that the student-teachers need to be given the opportunity to demonstrate comprehensive teacher competence rather than proving their accumulated fragmented theoretical knowledge (Billett, 2010; Sylte, 2018). The participants in this project experienced that this kind of authentic exam also leads to stronger coherence (Canrinus et al., 2015) between both theory and practice, and between the vocational teacher education at the university and the VET in upper secondary school. Authentic assessments such as the authentic exam described in this study, are assessments that involves supporting the job-relevant learning process towards comprehensive professional competence, which is based on the competence needed in the student-teachers professional practice as teachers in VET.

Based on the results of this project, the authors will continue to conduct the authentic exam in their vocational teacher education, but will also explore the possibility of filming the teaching sessions instead of traveling to the various schools as a solution to some of the logistic challenges to this assessment form.

Although the study's empirical context is in Norway, European research indicates that the problem of assessment of practical teacher competence in teacher education is not unique to Norway. As a result, it is highly likely that the challenges and opportunities that have been discussed in this research regarding an assessment of teacher competence in vocational teacher education in Norway also have relevance in a wider European perspective.

\section{Acknowledgement}

Author roles: The authors are equal. JD, HBO, ALS and ACW collected and analysed the data. All four authors have contributed the writing process. 


\section{References}

Antonovsky, A. (2000). Helbredets mysterium - At tåle stress og forblive rask [The Health mystery Tackling stress and keeping well]. Hans Reizel forlag.

Aspøy, T. N., Skinnarland, S., \& Tønder, A. H. (2017). Yrkesfagloerernes kompetanse [Vocational teachers' competence]. Fafo-rapport, 2017(11). Fafo.

Baartman, L., Gulikers, J., \& Dijkstra, A. (2013). Factors influencing assessment quality in higher vocational education. Assessment \& Evaluation in Higher Education, 38(8), 978-997. https://doi.org/ 10.1080/02602938.2013.771133

Billett, S. (2010). Learning through practice. In S. Billett (Ed.), Learning through practice. Models, traditions, orientations and approaches (pp. 1-20). Springer.

Billett, S. (2014). Integrating learning experiences across tertiary education and practice settings: A socio-personal account. Educational Research Review, 12, 1-13. https://doi.org/10.1016/j.edurev.2014.01.002

Billett, S., \& Choy, S. (2013). Learning through work: Emerging perspectives and new challenges. Journal of Workplace Learning, 25(4), 264-275. https://doi.org/10.1108/13665621311316447

Canrinus, E. T., Bergem, O. K., Klette, K., \& Hammerness, K. (2015). Coherent teacher education programmes: Taking a student perspective. Journal of Curriculum Studies, 49(3), 313-333. https://doi. org/10.1080/00220272.2015.1124145

Cochran-Smith, M., \& Lytle, S. L. (1993). Inside/Outside: Teacher research and knowledge. Teachers College Press.

Dewey, J. (1910). How we think. D. C. Heath.

Dreyfus, H. L., \& Dreyfus, S. E. (1986). Mind over Machine. The Power of Human Intuition and Expertise in the Era of the Computer. Free Press.

European Centre for the Development of Vocational Training. (2017). The changing nature and role of vocational education and training in Europe. Volume 2, Results of a survey among European VET experts. Publications Office. Cedefop research paper, No 64. http://dx.doi.org/10.2801/548024

Gessler, M. (2017). The lack of collaboration between companies and schools in the German dual apprenticeship system: Historical background and recent data. International Journal for Research in Vocational Education and Training, 4(2), 164-195. https://doi.org/10.13152/IJRVET.4.2.4

Goh, A. Y. S., \& Zukas, M. (2016). Student vocational teachers: The significance of individual positions in workplace learning. Journal of Vocational Education and Training, 68(2), 263-277. https://doi.or $\mathrm{g} / 10.1080 / 13636820.2016 .1172661$

Grimen, H. (2004). Samfunnsvitenskapelige tenkemåter [Ways of thinking in social research]. Universitetsforlaget.

Grollman, P. (2008). The quality of vocational teachers: Teacher education, institutional roles and professional reality. European Educational Research Journal, 7(4), 2008, pp. 535-547. https://doi. org/10.2304/eerj.2008.7.4.535

Gulikers, J. T. M., Runhaar, P., \& Mulder, M. (2017). An assessment innovation as flywheel for changing teaching and learning. Journal of Vocational Education \& Training, 70(2), 212-231. https:// doi.org/10.1080/13636820.2017.1394353

Haaland, G., \& Vagle, I. (2016). Profesjonsretting og forholdet mellom eksamensform og sluttvurdering [Professional relevance and the relationship between the exam form and final assessment]. In U. S. Goth (Ed.), Ny som loerer: Sjansespill og samspill. Tapir akademisk forlag. 
Hattie, J., \& Timperley, H. (2007). The power of feedback. Review of Educational Research, 77(1), 81112. https://doi.org/10.3102/003465430298487

Heggen, K., Smeby, J.-C., \& Vågan, A. (2015). Coherence: A longitudinal approach. In J.-C. Smeby \& M. Suthpen (Eds.), From vocational to professional education (pp. 70-88). Routledge.

Hiim, H. (2010). Pedagogisk aksjonsforskning: Tilnorminger, eksempler og kunnskapsfilosofisk grunnlag [Pedagogical action research: Approaches, examples and knowledge-philosophical base]. Gyldendal akademisk.

Hiim, H. (2013). Praksisbasert yrkesutdanning: Hvordan utvikle relevant yrkesutdanning for elever og arbeidsliv? [Practice-based vocational education: How to develop relevant vocational education for pupils and work life?]. Gyldendal akademisk.

Hiim, H. (2017). Ensuring curriculum relevance in vocational education and training: Epistemological perspectives in a curriculum research project. International Journal for Research in Vocational Education and Training, 4(1), 1-19. https://doi.org/10.13152/IJRVET.4.1.1

Hiim, H., \& Hippe, E. (2001). A utdanne profesjonelle yrkesutøvere [To educate professional practitioner]. Gyldendal akademisk.

Koenen, A.-K., Dochy, F., \& Berghmans, I. (2015). A phenomenographic analysis of the implementation of competence-based education in higher education. Teaching and Teacher Education, 50, 1-12. https://doi.org/10.1016/j.tate.2015.04.001

Lunenberg, M., Ponte, P., \& van de Ven, P.-H. (2007). Why shouldn't teachers and teacher educators conduct research on their own practices? An epistemological exploration. European Educational Research Journal, 6(1), 13-24, https://doi.org/10.2304\%2Feerj.2007.6.1.13

McNiff, J., \& Whitehead, J. (2006). All you need to know about Action Research. Sage Publications.

Miller, G. E. (1990). The assessment of clinical skills/competence/performance. Academic Medicine, 65, 63-67, https://doi.org/10.1097/00001888-199009000-00045

Ministry of Education. (2013). Forskrift om rammeplan for yrkesfagloererutdanning for trinn 8-13 [Regulation framework for vocational teacher education for levels 8-13]. Kunnskapsdepartementet [Ministry of Education]. https:/www.regjeringen.no/globalassets/upload/kilde/kd/pla/2006/0002/ ddd/pdfv/235560-rammeplan_laerer_eng.pdf

Ministry of Education. (2017). Loererutdanning [Teacher education]. https://www.regjeringen.no/ contentassets/d0c1da83bce94e2da21d5f631bbae817/kd_nasjonal-strategi-for-larerutdanningene_nett.pdf

Ministry of Education and Research. (2015-2016). Fag, fordypning, forståelse: En fornyelse av kunnskapsløftet [White paper on subjects, specialization, understanding: A renewal of knowledge-promotion]. Meld. St. 28 (2015-2016). https://www.regjeringen.no/no/dokumenter/meld.st.-28-20152016/id2483955/

Mulder, M. (2017). Competence-based vocational and professional education. Bridging the worlds of work and education. Springer International Publishing.

Nasjonalt Organ for Kvalitet i Utdanningen. (2006). Evaluering av allmennloererutdanningen i Norge 2006: Del1: Hovedrapport [Evaluation of general teacher education in Norway 2006, Part 1: Main report]. Nasjonalt organ for kvalitet i utdanningen (National Agency for Quality Assurance in Education). https://www.nokut.no/contentassets/40568ec86aab411ba43c5a880ae339b5/alueva_ hovedrapport.pdf

Patton, M. Q. (2015). Qualitative research \& evaluation methods. SAGE Publications.

Polany, M. (1996). The Tacit Dimension. Routledge Kegan Paul. 
Reason, P., \& Bradbury, H. (2008). Introduction. In P. Reason \& H. Bradbury (Eds.), The SAGE Handbook of Action Research: Participative inquiry and practice (pp. 1-10). Sage Publications.

Schön, D. A. (1983). The reflective practitioner: How professionals think in action. Basic Books.

Smeby, J.-C., \& Heggen, K. (2012). Coherence and the development of professional knowledge and skills. Journal of Education and Work, 27(1), 71-91. https://doi.org/10.1080/13639080.2012.718749

Stenhouse, L. (1975). An introduction to curriculum research and development. Heinemann.

Sullivan, W. (2005). Challenges to professionalism: Work integrity and the call to renew and strengthen the social contract of the professions. American Journal of Critical Care, 14(1), 78-80. https://pubmed.ncbi.nlm.nih.gov/15608113/

Sylte, A. L. (2014). Vurdering for yrkesrelevant opplæring [Assessment for relevant vocational education]. Nordic Journal of Vocational Education and Training, 4(1), 1-18. https://doi.org/10.3384/ njvet.2242-458X.14v4i1a4

Sylte, A. L. (2017). Didaktiske prinsipper for relevant yrkes- og profesjonsutdanning [Didactic principles for relevant vocational and professional education]. HiOA Avhandlinger [Ph.d.], 2017 nr. 11. Høgskolen i Oslo og Akershus.

Sylte, A. L. (2018). Profesjonsretting og studentaktivitet [Professionalisation and student activity]. Scandinavian Journal of Vocations in Development. https://doi.org/10.7577/sjvd.2694

Torrance, H. (2007). Assessment as learning? How the use of explicit learning objectives, assessment criteria and feedback in post-secondary education and training can come to dominate learning. Assessment in Education: Principles, Policy \& Practice, 14(3), 281-294. https://doi. org/10.1080/09695940701591867

Wahlgren, B., \& Aarkrog, V. (2012). Transfer: kompetence i en professionel sammenhoeng [Transfer: competence in a professional context]. Aarhus Universitetsforlag.

Winter, R. (1989). Learning from Experience. Principles and Practice in Action Research. Philadelphia Falmer.

Young, M. (2004). Conceptualizing vocational knowledge. Some theoretical considerations. In H. Rainbird, A. Fuller \& A. Munro (Eds.), Workplace learning in context (pp. 186-200). Routledge.

\section{Biographical Notes}

Jorunn Dahlback is Associate professor at OsloMet - Metropolitan University, Faculty of Teacher Education and International Studies. She has extensive experience with teaching and supervision at the Bachelor's degree in vocational teacher in design and craft, workplacebased vocational teacher education. Her research interests are vocationally relevant, competence-based and practice-based training, authentic and competence-based assessment. She has many years of experience in research within VET, is concerned with networking and collaboration between universities, schools and working life.

Hanne Berg Olstad is Assistant professor at OsloMet - Metropolitan University, Faculty of Teacher Education and International Studies. She teaches at the Bachelor program vocational teacher in design and crafts. Her research and development work is related to collaboration 
between universities, schools and working life, with a focus on organizing and content in the education.

Dr Ann Lisa Sylte is Associate professor at OsloMet - Metropolitan University, Faculty of Teacher Education and International Studies. She teaches and supervises at the master's program in VET and at the Ph.D. 's program. She has extensive experience in teaching and supervision at Postgraduate Certificate Teaching in Professional Education, vocational teacher education and master's degree in VET, as well as research work in vocational and professional education. Sylte is also a research-group manager. Her research work focuses on relevant vocational and professional education such as didactical principles for vocational and professional orientation of content, working methods and assessment, as well as collaboration between universities, schools and working life.

Anne-Catrine Wolden is Assistant professor at OsloMet - Metropolitan University, Faculty of Teacher Education and International Studies. She teaches at the Bachelor program vocational teacher in design and crafts. Her research and development work is related to the development of relevant VET, collaboration between universities, schools and working life, professional digital competence and further development of learning activities in vocational and professional education. 